\title{
INSURANCE AGAINST LIABILITY TO PAy STATUTORY FINES AND PenAlties
}

Chris Jurgeleit*

Contracts of insurance which deliberately insure a person against liability to pay fines or penalties have long been regarded as being contrary to public policy and therefore unlawful and unenforceable. So entrenched is this view that these sorts of contracts have not been a standard part of insurance companies' offerings and the courts have not had to deal specifically with any one-off such contracts as might have existed.

Now several insurers are offering, as a fairly standard component of their corporate/business/commercial packages, cover against liability for fines and penalties which may be imposed under certain pieces of recent legislation, particularly environmental, health and safety and consumer protection legislation.

This article examines the principles underlying the view that fines and penalties insurances are unlawful, and discusses an alternative argument and its chances of success in the context of Resource Management Act offences.

\section{THE NEW INSURANCES}

The new policies cover offences under (for example) the Resource Management Act 1991 ("RMA"), the Building Act 1991, the Health and Safety in Employment Act 1992, the Fair Trading Act 1986 and the Consumer Guarantees Act 1993. Typically they offer indemnities against liability for fines and penalties incurred under those Acts, and in respect of the costs of defending offence proceedings. Mostly they form part of the insurer's package for companies and company directors - they are made up of separate company, company reimbursement and directors' and officers' policies.

Cover is generally available only where the event or act constituting or giving rise to the offence was:

- Barrister and Solicitor of the High Court of New Zealand. 
(i) unintended and unexpected; and

(ii) not the result of a deliberate or reckless disregard for the provisions of the Act or for notices or orders made under the Act.

Some policies do not exclude intentional or expected acts. Frequently it will be a condition of cover being available that the offender has used due diligence and taken all reasonably practicable steps to avoid or diminish a claim under the policy.

\section{THE TRADITIONAL VIEW: CONTRARY TO PUBLIC POLICY}

It appears there is no case where a court has considered the validity of a contract of insurance which deliberately and expressly sets out to insure a person against liability to pay (statutory) fines or penalties. Nor are there cases where, under a contract of insurance to insure against liability generally for certain types of acts, an insured has claimed to be indemnified for fines payable in consequence of those acts. Nevertheless it is usually accepted that at common law a contract to insure against liability to pay fines and penalties is contrary to public policy and void.

The basis for the accepted view is the maxim ex turpi oritur causa non oritur actio literally, "an action does not arise from a base cause". The maxim has been put in many ways. For example: ${ }^{1}$

No Court will lend its aid to a man who founds his cause of action upon an immoral or an illegal act. If, from the plaintiff's own stating or otherwise the cause of action appears to arise ex turpi causa, ... there the Court says he has no right to be assisted ... .

And: ${ }^{2}$

It has, I think, long been settled law that if an act is manifestly unlawful, or the doer of it knows it to be unlawful, as constituting either a civil wrong or a criminal offence, he cannot maintain an action for contribution or for indemnity against the liability which results to him therefrom. An express promise of indemnity to him for the commission of such an act is void.

Where the courts have considered the availability of an indemnity for the consequences of civil wrongs, they have gradually moved away from a strict interpretation of the principle, qualifying it so that it applies primarily to intentional or criminal acts. It has been the natural nexus between criminal acts and offences that has led to the view that any contract to insure against fines imposed for the commission of offences is contrary to public policy.

1 Holman $v$ Johnson (1775) 1 Cowp 341, 343.

2 Burrows $v$ Rhodes [1899] 1 QB 816, 828. 


\section{A Companies Legislation}

The received common law position is reflected in the New Zealand companies legislation in relation to the indemnification and insuring of company directors. Under s 204 of the Companies Act 1995 ("1955 Act") and s 162 of the Companies Act 1993 ("1993 Act"), a company is precluded from indemnifying or effecting insurance for its directors or employees in respect of any criminal liability those persons might incur, or in respect of any costs they might incur in defending any criminal proceedings (unless they are acquitted from such proceedings).

\section{B Comment}

There is little detailed writing in support of the traditional view - probably because it has been taken so much for granted. However, the authors of an Australian text on liability insurance have this to say:

If the legislature, which is the arbiter of public policy, provides that an act or activity should be visited with a penalty upon a person coming within a prescribed situation, then that should not be mitigated by an insurer. .... Insofar as the legislation imposes a penalty as such, the courts are unlikely, at least for some time, to look at the philosophical foundation of the penalty in order to decide whether it may be the subject of indemnification by the policy. The proper view should be that if the legislature invokes a penalty, then it should be borne by the person upon whom it is imposed.

While no doubt it is possible and desirable to insure against liability to a third party for breach of a statutory duty, which of course may also flow from such conduct, the position is different in respect of a penalty no matter how large. It is the purpose of the particular act to inflict a penalty on he who infringes, and if the penalty is made very large, the obvious purpose is that it should act as a deterrent. It would run counter to the intention of the legislature if the insured could divest himself of the punishment and its effects, by insurance.

And in the mid-1930s one British insurer issued a circular offering to insure motorists against liability to pay fines for certain road traffic offences, most of them minor, but including failure to stop at traffic signals and exceeding the speed limit. That drew the following comment: ${ }^{4}$

It is obvious that to insure potential offenders against the penal consequences of their breaches of the law is against public policy as tending to make punishment nugatory and as encouraging persons in the very kinds of carelessness or even recklessness against which the law, in the public interest, has attempted to impose safeguards.

3 Derrington and Ashton The Law of Liability Insurance (Butterworths, Sydney, 1990) 54.

4 "Insurance Against Fines" (1936) 100 JPLGR 248. 
It seems to us doubtful whether an insurance policy covering these risks is valid, but of course such a class of insurance business could be successfully built up on good faith, the insurers taking no advantage of the legal flaw in their contract. But, in our opinion, the plan of insurance involves the commission of an offence. Offering to insure against this risk, and issuing policies are acts to the public mischief.

The common law misdemeanour of doing an act to the public mischief must not be used too freely. It is capable of almost indefinite extension. But if wasting police time on enquiries into pretended crime is an act to the public mischief, a fortiori making idle the sanctions which make police control of traffic effective is such an act.

We are inclined to go further and to suggest that insurers and insured are guilty of a conspiracy to prevent or to defeat the course of public justice, which intends that the punishment of fine shall attach to an individual and not be resolvable into a levy of infinitesimal amount on each of a large number of persons who are strangers to him and the transactions in which he has been concerned.

It may perhaps be regarded by the authorities as impolitic to invoke the ancient common law to deal with the modern mischief. If so the sooner the matter is dealt with by Parliament the better.

Derrington and Ashton, besides taking a less outraged stance on the behaviour of insurers and insureds in contemplating such insurances, concede that the increase in legislation imposing penalties in areas such as environmental protection will inevitably give rise to questions about the correctness or appropriateness of the current common law position.

\section{THE TRADITIONAL VIEW CHALLENGED}

In 1983, in a paper to the Australian Legal Convention ${ }^{6}$, Professor K C T Sutton has suggested that there is no such blanket "external" prohibition on insurance against fines on the ground of public policy. He discusses cases where the courts have qualified the ex turpi causa principle in relation to insurance or indemnity for the civil consequences of criminal acts. He concludes generally that similar qualifications should apply where there is a claim for indemnity in respect of fines payable for the commission of statutory offences. He argues that there is no overriding public policy justification for prohibiting all such insurances, but rather that the public policy reasons for and against permitting indemnification differ from case to case and that the decision as to indemnity should depend on the circumstances of the particular case.

Above $n$ 3, 54 . 


\section{A Fire and All Risks Insurance Co Ltd $v$ Powell}

Professor Sutton draws heavily on the judgment of the Supreme Court of Victoria in Fire and All Risks Insurance Co Ltd $v$ Powell. ${ }^{7}$ In that case a carrier had deliberately ignored a statutory provision prohibiting the use of vehicles over a certain height on the roads except under a special licence. He had driven his truck with a high load, without a permit, and in doing so had encountered a bridge too low to allow the truck to pass safely under it. (If he had obtained a permit it would have notified him that he could not drive safely on that road.) Goods on the truck were damaged and the owner of the goods sued the carrier. The carrier made a claim on his insurers. The insurers argued that:

(i) there was no indemnity because the carrier by his own wilful act had caused or contributed to the loss in respect of which he claimed indemnity; and

(ii) as the loss arose in the course of the carrier's doing an intentionally illegal act, the carrier was, as a matter of public policy, precluded from recovering under his insurance policy.

The insurers' first argument did not rely on the wilful act being an unlawful act. The court accepted that: ${ }^{8}$

It is a fundamental term of all insurance law that the insured is debarred by an implied term from recovering on the policy if he intentionally caused the loss or the event upon which the insurance moneys were expressed to be payable.

but distinguished between an intentional act which produces intentional loss or damage and an intentional act in the course of doing which unintended loss or damage occurs, saying: ${ }^{9}$

The true rule is that where the actual loss for which indemnity is sought is deliberately contrived by the insured's wilful and deliberate act, he cannot recover under the policy, but that his negligence does not bring him within that concept.

The insurer's argument failed. The court held that the proximate cause of the damage was not the (unlawful) failure to obtain a permit, but driving the truck under the bridge. That was a negligent, not an intentional act. Nor did the carrier intend to cause damage to the goods on the truck. It is not contrary to the principles of insurance law to insure against the (unintended) consequences of negligence.

7 [1966] VR 513.

8 Above $n$ 7, 517.

$9 \quad$ Above $n$ 7, 519. 
In relation to the second argument the court traversed a number of cases dealing with the circumstances in which it is contrary to public policy to allow an insured to recover under an insurance policy for liability to pay civil damages. It noted the conflict between two broad and established principles of public policy:

(i) that persons who enter into contractual engagements should be required to fulfil them (particularly where the contract is one of insurance in relation to a commercial transaction, "for without insurance it would be difficult to carry on modern commerce");

(ii) that no person ought to be able to recover in an action at law anything which in substance will come to him as a benefit from his crime.

As to the latter principle, the court picks up from earlier, similar cases comments to the effect that the rule is not by any means an inflexible one. For example, in Cleaver v Mutual Reserve Fund Life Association the court had said: ${ }^{10}$

... that the person who commits murder, or any person claiming under him or her, should be allowed to benefit by his or criminal act, would no doubt be contrary to public policy. But this doctrine ought not to be stretched beyond what is necessary for the protection of the public.

Lord Wright MR said in Beresford v Royal Insurance Co Ltd: ${ }^{11}$

While the law remains unchanged [ie the law which makes suicide a crime] the Court must, we think, apply the general principle that it will not allow a criminal or his representative to reap by the judgment of the Court the fruits of his crime. We have quoted the above authorities in support of that principle, which is of general import. The principle has been applied not only in the authorities quoted above but also in many decisions dealing with varied states of fact and applications of the same or similar principle. These are all illustrations of the maxim ex turpi causa non oritur actio. The maxim itself, notwithstanding the dignity of a learned language, is, like most maxims, lacking in precise definition. In these days there are many statutory offences which are the subject of the criminal law, and in that sense are crimes, but which would, it seems, afford no moral justification for a Court to apply the maxim. There are likewise some crimes of inadvertence which, it is true, involve mens rea in the legal sense but are not deliberate or, as people would say, intentional.

And in St John Shipping Corporation $v$ Joseph Rank Ltd ${ }^{12}$ Lord Devlin (then Devlin J) had questioned whether the rule applied at all to statutory offences.

10 [1892] 1 QB 147, 152.

11 [1937] 2 KB 197, 219.

12 [1957] 1 QB 267, 292. 
The Powell court concluded that: ${ }^{13}$

...it is not the law that every act deliberately done and which is prohibited by law - whether by the common law, by statute or by by-law or statutory regulation - and which is, whether remotely or directly, causally connected with a loss which is the subject of indemnity under an insurance policy, so operates on the contract of indemnity that the courts are bound on the ground of public policy to deny to the actor the benefit of his contract. Such a doctrine would be mischievous in the extreme.

It went on to say that: ${ }^{14}$

...in every case, in which it is sought to avoid performance by one party to a contract of a promise contained therein on the ground that public policy will not permit the law's processes to assist a man to secure a benefit said to arise from his own criminal act, the court must consider whether the act of the promisee is of such an anti-social character that the interests of the public require that the courts should for their protection decline to enforce the contract.

Again the insurers failed. The court considered that even if the damage had been caused directly by the carrier's unlawful conduct in not obtaining a permit, that conduct was not so grave or anti-social as to preclude indemnity for the loss that followed. The failure to obtain a permit was not a crime in the sense that it would shock the conscience of reasonable people or cause them to regard the carrier as a criminal. It was a breach of a "mere" regulatory provision (it was in fact a breach of the Act, though the court obviously considered the provision to be of "regulatory" character). The legislation provided for a penalty, which was sufficient for the protection of the public. It was not going to help deter future offenders for the court to refuse to allow the indemnity - most carriers would consider it better to carry the goods safely than to be insured for their damage. The interests of victims (those whose goods were harmed) were promoted by the existence of the indemnity. The defendant, though he knew he was breaking the law, did not expect to cause anyone harm. Finally, the insurer could have excluded cover for losses incurred in the course of a wilful infringement of the Act. It was unsatisfactory for the insurer, who had contracted to insure and kept the premiums, to be able to refuse to honour his promise.

\section{B Professor Sutton's Argument}

Professor Sutton argues that the validity of policies to insure against fines should be tested by the criteria laid down in Powell if the offences committed or fines imposed are the unintended consequences of intended (or negligent or accidental) acts. If the consequences of

13 Above n 7, 523.

14 Above n 13. 
an act are intended, the cover will be precluded anyway - if not by the words of the policy, by ordinary principles of insurance law relating to its construction.

He justifies that argument by pointing out that nowadays the breach of a statute is not necessarily regarded as involving immorality or impropriety - especially where strict liability is imposed and neither intention nor negligence is required to prove the breach. Often strict liability is imposed not (or not primarily) for deterrent purposes, but for other reasons, eg to provide a fund for repairing damage.

\section{Other Justifications}

There are other reasons why the orthodox view might legitimately be challenged. A fine will have no deterrent effect on a person who is convicted but in no way at fault. And it would be punishment of a person society considers innocent. That concept is outside our notions of justice and fairness. Furthermore we accept that negligence is a part of everyday life, notwithstanding that society might prefer that it was not. On the whole people will prefer to take care rather than to act carelessly and cause damage, even though that damage is insured against. A fine imposed in those circumstances will have little more deterrent effect than one imposed on a completely "innocent" person. As to whether Parliament's intention to punish would be undermined by allowing insurance, it should not be forgotten that persons insured will still be personally liable to pay premiums and deductibles. Those are likely to be significant and to increase in size as more claims are made, so that repeat offenders will be deterred.

The sorts of legislation for which insurance against fines is being offered has its greatest impact on the industrial and commercial communities. As industry and commerce become more highly regulated by statute there is a risk that if statutory penalties are not insurable, businesses will fail or become excessively risk-averse. It is already a concern that the increasing legal obligations being imposed on company directors, for example, will impact adversely on their decision whether to serve or continue to serve on company boards. Alternatively they may agree to serve but insist on overly cautious risk-reduction measures, or even contract out the risky decisions to professional advisers. Companies will end up being unable to create boards composed of dynamic, successful business leaders. The same sorts of concerns arise outside of the corporate area in small business ventures. Enterprise will be stifled. The certainty necessary for efficient business management will be threatened.

\section{APPLYING THE POWELL REASONING}

If the New Zealand courts could be persuaded to reexamine the accepted common law position and apply the principles that emerge from Powell, one would expect their approach to be to accept that the policy is valid per se, to identify the particular circumstances in which the insured claims an indemnity, and to weigh the public policy factors for and 
against allowing the indemnity in that particular case. The sorts of factors that might be taken into account include, for example:

(i) The nature and gravity of the illegal conduct - Is it a crime in the sense that it shocks the conscience of reasonable people, or causes them to regard the offender as a criminal, or as so anti-social that courts should decline to enforce the contract of insurance in order to protect the public? Is the offence a truly criminal one, or is it regarded as a regulatory or public welfare offence?

(ii) The extent to which allowing the indemnity will hinder any deterrent effect the law was intended to have - If the provision was enacted purely or primarily for its deterrent effect, will it actually deter the offender or future offenders if imposed in the particular circumstances? Was the offending purely inadvertent, so that no punitive response will be sure to prevent its recurrence? Is the opprobrium that attaches to the conviction deterrent enough in itself?

(iii) The potential for encouraging similar future acts if the indemnity is allowed - Will those insured under these policies prefer to cause damage and recover under their insurance policies rather than to avoid the damage altogether? Are there other sanctions that will make the offender prefer to avoid the damage - for example loss of customer satisfaction, poor corporate image?

(iv) The purpose of the statutory provision that was infringed - Was it enacted purely or primarily for deterrent purposes, or does it have some other objective? Provision in the relevant Act for moneys recovered as fines to go to a "clean-up fund" may well suggest another dominant purpose.

(v) The offender's knowledge of facts or law making his conduct a crime - In subjective terms, was the offender's conduct morally reprehensible, so that it warrants a punishment that will be borne personally?

(vi) Whether enforcement of the indemnity would promote or be detrimental to the interests of innocent victims - Do the fine moneys go to a fund to repair damage caused by the event insured against? Or to a general fund to promote the Act's purposes generally? Or to fund education to prevent future offences? If so, will the offender be able to pay the fine if the indemnity is not allowed?

The question is whether our courts, if and when they are confronted by the issue of the validity of one of these policies, will be persuaded by arguments along the lines proposed by Professor Sutton, or whether they will stick to the basic premise that all such insurances are void from the beginning. Some indications may be available from cases already decided under the offence provisions of the various statutes. So far as the Resource Management Act 1991 ("RMA") is concerned there is already some useful guidance from the courts. 


\section{$V$ OFFENCES UNDER THE RESOURCE MANAGEMENT ACT}

Under $s$ 338(1) of the RMA it is an offence to contravene or permit the contravention of any of $s 9$ (use of land in contravention of district or regional plans), $s 11$ (restrictions on subdivision), s 12 (restrictions on use of coastal marine areas), s 13 (restrictions on uses of beds of lakes and rivers), s 14 (restrictions relating to water) or s 15 (discharge of contaminants into the environment). Any person convicted of an offence under $\mathbf{s} 338(1)$ is liable to a maximum term of imprisonment of 2 years or a fine of up to $\$ 200,000$, and $\$ 10,000$ per day while the offence continues. ${ }^{15}$

Whether the defendant intended to commit the offence is irrelevant ${ }^{16}$. A defence is available where the contravening action or event was necessary, ${ }_{17}$ or beyond the control of the defendant, ${ }^{18}$ provided in both cases that the effects of the action or event were adequately mitigated or remedied by the defendant after it occurred.

Where an offence is committed by a person acting as agent or employee, the person's principal is liable under the Act in the same manner and to the same extent as if he, she or it had personally committed the offence, but in those circumstances a defence of no-fault is available to the principal, again provided that the principal took all reasonable steps to remedy any effects of the act or omission giving rise to the offence ${ }^{19}$.

Where a company is convicted of an offence, every director and person concerned in the management of the company is also guilty of the offence, if:

(i) the act that constituted the offence took place with their authority or permission or consent; and

(ii) they knew or could reasonably be expected to have known that the offence was to be or was being committed and failed to take all reasonable steps to prevent or stop it. ${ }^{20}$

\section{A The Machinery Movers Case}

In Machinery Movers Ltd $v$ Auckland Regional Council ${ }^{21}$ the High Court (Full Court) considered an appeal against the sentence imposed by the District Court for breach of

\footnotetext{
15 RMA s 339(1).

16 RMA s 341(1).

17 RMA s 342(2)(a).

18 RMA s 341(2)(b).

19 RMA s 340.

20 RMA s 340(3).

21 [1994] 1 NZLR 492.
} 
s 15(1)(b) of the RMA (discharge of a contaminant onto land in circumstances which resulted in that contaminant entering water).

Machinery Movers Ltd ("MML") had been engaged to empty and remove a number of storage tanks from a timber yard. The company that engaged MML had obtained written permission from the Regional Council to discharge the contents of the tanks (described as contaminated stormwater containing traces of zinc napthenate) into the Council's sewerage system at the timber yard. Diluted zinc napthenate is comparatively harmless. MML saw the Council's letter of permission.

MML's employees could not find the sewerage outlet manhole, so they discharged the contents of the tanks onto the ground over a period of a day or so. One of the tanks in fact contained serious levels of very toxic chemicals. One of MML's directors discovered that fact at a fairly early stage in the discharge process but did nothing about it. The discharge filtered into a nearby stream. Ducks died. Members of the public had to be treated for the effects of the chemicals.

The District Court had convicted MML of an offence under s 15(1)(b) and had imposed a fine of $\$ 25,000$ and ordered MML to pay the costs of the prosecution, amounting to about $\$ 11,000$. MML had also paid the costs of cleaning up the spill.

MML argued that the fine was excessive. The High Court disagreed. In the course of dealing with an argument by counsel that sentencing considerations under the RMA should be similar to those under its predecessor Act (the Water and Soil Conservation Act 1967) the court said that the RMA was informed by a wholly different environmental philosophy which places far greater emphasis on environmental protection and introduces a much more stringent regime of penalties and punishment that did the 1967 Act: $^{22}$

A power to imprison has been added and the maximum fine increased by one third from $\$ 150,000$ to $\$ 200,000$. In addition, $\$ 340$ (2) of the RMA has introduced separate criminal liability for company directors and managers of corporations subject to proof of lack of due diligence.

Those changes, the court said: ${ }^{23}$

....constitute a clear legislative direction to the Courts to ensure that higher penalties are imposed which will have a significant deterrent quality. If fines are too low, they will be regarded as a minor licence fee for offending and convey the idea that the law may be broken with relative impunity.

22 Above n 21, 500, (emphasis added).

23 Above $\mathbf{n} 22$. 
The court went on to consider what were the sentencing principles in pollution cases. It took those primarily from $R v$ Bata Industries $L t d,{ }^{24}$ in which Bata and its directors were convicted and fined under Ontario state legislation for causing a discharge into the natural environment. Many of the matters considered relevant for sentencing purposes coincide with the public policy factors which Professor Sutton suggests should determine the issue of indemnification. It is useful to look at the position the court took on those matters.

By way of general overview, the Bata Court said, and the High Court agreed, that: ${ }^{25}$

Breaches of these regulations and laws must be dealt with in such a fashion as to prevent their repetition and to foster the principle of environmentally responsible corporate citizenship.

The purpose of sentencing an offender is to protect the public, to deter and rehabilitate the offenders, to promote compliance with the law, and to express public disapproval of the act.

There are unique sentencing considerations to bear in mind in public welfare offences, but there can be no doubt that the protection of the public is the primary consideration in sentencing in this field.

The High Court also agreed that the severity of the sentence should vary in accordance with the nature of the environment affected, the extent of the damage, the deliberateness of the offence, the attitude of the offender, and in the case of corporate offenders, the size, wealth, nature of operations and power of the corporation, the extent of its attempts to comply, remorse, profits realised by the offence, and the existence of a criminal record or evidence of good character.

Protection of the public was seen as best achieved by general deterrence - by emphasizing community disapproval of an act and branding it as reprehensible, but not by making the penalty so severe that it will "over-deter" by making companies reluctant to abate environmental damage. The Bata Court had also recognised the tension between imposing punishments which might undermine a company's stability and protecting the environment, and resolved that tension in favour of protection of the environment: ${ }^{26}$

The message [corporations] receive from this sentence must be that even in this bleakest of financial times, the environment must not be a sacrificial lamb on the altar of corporate survival.

24 (1992) 9 OR (3d) 329 (liability); 7 CELR (NS) 293 (sentencing). Discussed in Machinery Movers, above n 21, 502-506.

25 Above n 21, 503.

26 Above n 21, 504. 
With all of that the High Court agreed. More specifically, in Bata it had been ordered under the terms of probation imposed that Bata was not to indemnify its directors for the fines they had to pay. That condition was unsuccessfully appealed with the appeal court holding that the objective of the executives' sentence required that they pay the fines personally. ${ }^{27}$ Noting that the question of an indemnity was not one that was before it, the High Court nevertheless expressed its general approval of the condition prohibiting an indemnity, saying:

... it would be against public policy for the company to give an indemnity relating to the criminal conduct of directors....If a director is acquitted indemnification is permissible in respect of costs: $s 204$ of the Companies Act 1955. Condition 6 may have been included because of the fact that the offences were public welfare offences only.

The High Court in Machinery Movers was persuaded to some extent by an argument that the size of the penalty was out of proportion to the financial position of the company. Counsel argued that the total financial impact of the penalty would inevitably place a severe strain on the company's financial resources and might even push it over the financial edge and cause it to cease trading. The court noted that the trial judge had taken into account the company's financial position in arriving at the sentence and concluded that the penalty was not excessive, but that it was important that the fine should not place the company at risk, - "especially in the current climate where the continuation of employment is so important". It amended the sentence to permit the fine to be paid in instalments over two years.

\section{B Machinery Movers and Sutton's View}

Professor Sutton has argued that fines imposed for certain pollution offences ought to be insurable. In particular he thought that insurance ought to be available where noncompliance with minimum standards was accidental or negligent, or where it was unrealistic to expect compliance with the governing legislation, for example, where it was

27 Bata further appealed the non-indemnification provision in the probation order. The decision of the Ontario Court of Appeal on that further appeal (127 DLR (4th) 438) became available shortly after this article was written. On appeal the non-indemnification provision was held inappropriate and was struck out, on the bases that:

(i) it was made for a collateral purpose (to punish two parties not subject to the order); and

(ii) the question whether an indemnity is available is one to be decided under corporations legislation.

The relevant legislation (s 136 of the Ontario Business Corporations Act, RSO 1990, c B 16) provides that a company may indemnify directors if the directors acted honestly, in good faith with a view to the best interests of the corporation, and in the reasonable belief that their conduct was lawful.

28 Above n 21, 506. 
prohibitively expensive for a company to eliminate every chance of pollution arising from its activities (provided that what was being insured was contingent and not certain).

From dicta in Machinery Movers it seems unlikely that our courts will accept arguments of that sort, at least in the context of RMA offences. There is a defence under the RMA where an act constituting an offence is beyond the control of the offender. Given the court's determination that Machinery Movers should pay the full penalty imposed, even though that might threaten the company's viability, it is difficult to see a later court accepting the proposition that, if it is economically unrealistic for an offender to pay a fine, then this should be grounds for condoning an indemnity from insurers.

There was no issue of indemnity or insurance in Machinery Movers. But the way in which the court approached its sentencing function, and its obiter comment approving the prohibition on indemnity in Bata, suggest that the factors which Professor Sutton argues should go to the availability of indemnity were in fact taken into account in determining the sentence. The High Court said, for example, that:

(i) The offence was a serious one, with particularly traumatic and severe effects, and one which deserved public disapproval.

(ii) The incident ran wholly counter to the general purposes of the RMA.

(iii) The fine needed to be pitched at a level which would make it a real deterrent and not risk it being regarded as a "licence fee".

(iv) The fine was still well below the maximum penalty under the Act.

(v) It was accepted that Machinery Movers had taken steps to mitigate or remedy the effects of the discharge.

(vi) The discharge was not intentional, but negligent, with unintended and unforeseen consequences, but that did not mean there was a low level of moral culpability.

(vii) It was accepted that Machinery Movers had already had to pay the clean up costs of the incident, and that that in itself had some deterrent value.

(viii) It accepted that Machinery Movers was a small operation, but it did not for that reason deserve to be treated more leniently.

The court set the level of the fine in recognition of those factors. And by refusing to lessen the fine to preserve the financial viability of the company (even though it acknowledged the imperative of protecting employment opportunities) the court indicated, at least implicitly, indicated that these were fines which were intended to cause pain to the offender itself. Even if an (uninsured) offender could not pay the fine without risking going out of business, that would be dealt with, not by reducing the offender's personal liability 
(as fines and penalties insurances would), but by ameliorating the terms of payment. It may therefore be of no avail to argue, for example, that the insured offender personally pays premiums, and a deductible for each insured offence. Premiums and deductibles can be pitched at a level that will not cause embarrassment for the insured. The penalty imposed by the court is intended to do just that - to punish and deter the offender personally. And so far as offences under the RMA are concerned they should probably, for the present at least, be regarded as criminal offences (or at least public welfare offences so serious that they warrant similar treatment), so that indemnities given or insurances effected to avoid their consequences would be amongst those prohibited under the Companies legislation.

The same may not be true for all fines and penalties insurances. Courts may take a different view of offences and penalties under other Acts for which fines insurance is now being offered. Each Act and the decisions made under it will have to be examined individually to see whether there is scope for arguing that the insurances are not necessarily contrary to public policy.

\section{CONSEQUENCES FOR COMPANIES EFFECTING FINES AND PENALTIES INSURANCES}

From the example of the RMA cases, it appears that insurance against liability for fines is in fact insurance against the consequences of criminal acts and contrary to public policy. If this is the case, what are the implications for a company taking out insurance of that kind for itself and/or its directors?

In the first place the contract of insurance is likely to be void, either under the Companies legislation, or under the Illegal Contracts Act 1970, or by a combination of the provisions of both. Technically, the contract will be unenforceable against the insurer. Directors who have entered into such contracts on behalf of their company or who have caused their company to grant indemnities or effect insurance in breach of the Companies legislation could face claims from shareholders or from the company. Directors may have to pay the costs of the insurance personally. ${ }^{29}$ Otherwise there appear to be no sanctions against companies or directors who might take insurance of this sort.

It is probably unlikely, except perhaps in the event of a change in company shareholding or upon liquidation of a company, that there would be any internal company dispute over the enforceability of an indemnity or the effecting of directors' and officers' insurance. Similarly, except where an insurance company changes hands or goes into liquidation, it is improbable that an insurer would refuse to honour a fines policy, because of the damage that would do to its commercial reputation. 
Is the question whether these insurances are contrary to public policy then a purely academic one? The answer must be that it is not. The courts are alive to the possibility of a company indemnity in respect of fines payable by company directors, and they will almost certainly soon come across an offender who is insured against liability for a fine. In either case there is room for argument on the public policy issue, but for Resource Management Act offences in particular, the chance of a move away from the accepted common law position is probably remote. 